\title{
Changes in crude oil hydrocarbon composition during biodegradation by Arthrobacter sp. M1 and Acinetobacter sp. Pr82 in selected optimal conditions
}

\author{
Indrè Gailiūtét $\dot{e}^{1,2 *}$, \\ Gražina Račkauskienè $\dot{1}^{1}$ \\ Saulius Grigiškis ${ }^{1,3}$ \\ "JSC "Biocentras", \\ V. A. Graičiūno str. 10, \\ LT-02241 Vilnius, Lithuania \\ ${ }^{2}$ Vilnius University, \\ Institute of Biotechnology, \\ V. A. Graičiūno str. 8, \\ LT-02241 Vilnius, Lithuania \\ ${ }^{3}$ Vilnius Gediminas \\ Technical University, \\ Sauletekio al. 11, \\ LT-10223 Vilnius, Lithuania
}

\begin{abstract}
One of the perspective areas for biotechnology application is the clean-up of environment contamination by oil hydrocarbons. The above biotechnology is based on the ability of some microorganisms to degrade crude oil and oil products. Among the oil hydrocarbon degrading microorganisms, the bacteria of genus Arthrobacter and genus Acinetobacter are especially attractive for biotechnological applications, as they are widespread in the environment and are able to survive in extreme conditions (Levišauskas et al., 2004; Towner, 2006). The aim of this work was to select optimal conditions (inoculum age, inoculum volume, temperature, $\mathrm{pH}$, concentration) for microbial strains degrading crude oil and to research how SARA fractions (saturated compounds, aromatic compounds, resins, asphaltenes) change in composition after crude oil degradation in optimal conditions. Two strains Acinetobacter sp. Pr82 and Arthrobacter sp. M1 were obtained from the culture collection of JSC "Biocentras" and used for investigations. Research results show the best degradation intensity of saturated hydrocarbons by Acinetobacter sp. Pr82 and Arthrobacter sp. M1; much lower degradation was of aromatic compounds, resins and asphaltenes.
\end{abstract}

Key words: crude oil, Arthrobacter sp., Acinetobacter sp., biodegradation, SARA (saturates, aromatics, resins, asphaltenes) fractions

\section{INTRODUCTION}

Crude oil and petroleum products are a complex mixture of hydrocarbons and other organic compounds, including some organometallo-constituents (Atlas, 1981; Van Hamme et al., 2003). Petroleum constituents are represented by saturates, aromatics, resins and asphaltenes (Leahy and

\footnotetext{
* Corresponding author. E-mail: indre.gailiute@biocentras.lt
}

Colwell 1990; Singh, 2006). These fractions and their derivatives are the main pollutants in the environment. They are a serious concern worldwide, because of the hazard they pose to the health of humans and animals (Gailiūte et al., 2011). Saturates are defined as hydrocarbons containing no double bonds. According to their chemical structure, they are categorized into alkanes (paraffins) and cycloalkanes. Saturates represent the highest percentage of crude oil constituents. Aromatic 
hydrocarbons with one or several aromatic rings are usually substituted with different alkyl groups. In comparison to the saturated and aromatic fractions, the resins and asphaltenes contain non- hydrocarbon polar compound. Resins and asphaltenes have a very complex and mostly unknown carbon structure with the addition of many nitrogen, sulphur and oxygen atoms (Harayama et al., 2004). Petroleum recovered from different reservoirs varies widely in composition and physical properties. The composition of particular petroleum products ranges from the lowest molecular weight hydrocarbons to the highest. Light hydrocarbons have higher solubility and volatility compared to heavy hydrocarbons, making them much quicker spreads to the soil and migrate. Light hydrocarbons in higher concentrations are found in the new pollution due to the high solubility and volatility, making them easier to remove (Amro, 2004). Due to the low solubility in the soil heavy hydrocarbons migrate slower they are absorbed on the surface of soil particles and contaminate the soil (Toledo et al., 2006). Old polluted sites were dominated by difficult to break down heavy hydrocarbons, which are difficult to remove.

Microorganisms that degrade oil hydrocarbons are found in almost all types of soil and waste water; however, their existence does not guaranty the affective degradation of oil pollutants. The amount of oil-oxidizing microbes becomes greater when their environment is polluted with hydrocarbons (Saadoun et al., 2008).

In our work we used two microbial strains: Acinetobacter sp. Pr82, that was isolated from black soil contaminated with heavy petroleum products near Kaliningrad in Russia and Arthrobacter sp. M1 that was isolated from water contaminated with heavy petroleum hydrocarbons for a prolonged period near Jonava in Lithuania.

The chemical structure of hydrocarbon affects their biodegradation. In the oil-forming compounds, the majority of microorganisms break down easily with low molecular weight linear, branched, cyclic and aromatic hydrocarbons. Long-chain alkanes and polycyclic aromatic hydrocarbons are considered difficult to degrade compounds due to their increased hydrophobicity (Zhang et al., 2011).

The length of oil-oxidizing microorganisms' growth and biological degradation depends on many environmental factors. The main factors determining the effectiveness of degradation are as follows: hydrocarbon mixture composition, physical properties, temperature, nutrient availability, $\mathrm{pH}$, microorganisms (Fritshe and Hofrichter, 2008; Montiel et al., 2009). Unfavourable environmental conditions, hydrocarbons can remain unchanged indefinitely, but under favourable conditions can be cleaved in a few days or hours (Akpor et al., 2007).

\section{MATERIALS AND METHODS}

Crude oil used in this study was obtained from oil refining company "Orlen Lietuva", located in Mažeikiai, Lithuania.

Microorganisms. Arthrobacter sp. M1 and Acinetobacter sp. $\operatorname{Pr} 82^{*}$ were obtained from the culture collection of JSC "Biocentras" and used for degradation experiments of crude oil. ${ }^{*}$ In publications until 2014, bacterial strain PR82 was assigned to the genus Arthrobacter (established by a microbiological method). After sequencing bacterial strain Pr82 was assigned to the genus Acinetobacter.

Media. Nutrient agar (Oxoid, Basingstone, UK) was used for plating bacterial strains, and nutrient broth (Oxoid, Basingstone, UK) was used for the subculture and preculture of the strains. To investigate the ability of the strains to degrade crude oil, a mineral medium was used. The mineral medium had the following composition (g/L): $0.01\left(\mathrm{NH}_{4}\right)_{2} \mathrm{HPO}_{4} ; 0.2 \mathrm{NH}_{4} \mathrm{Cl}$; $0.25 \mathrm{~K}_{2} \mathrm{HPO}_{4} ; 0.25 \quad \mathrm{KH}_{2} \mathrm{PO}_{4} ; 0.02 \quad \mathrm{MnSO}_{4}$; $0.01\left(\mathrm{NH}_{4}\right)_{2} \mathrm{Fe}\left(\mathrm{SO}_{4}\right)_{2} \cdot 6 \mathrm{H}_{2} \mathrm{O} ; 0.01 \mathrm{CaCl}_{2}$ and 0.05 $\left(\mathrm{CH}_{3} \mathrm{COO}\right)_{2} \mathrm{Zn}$. Mineral agar was used for cultivation and enumeration of hydrocarbon degrading microorganisms. Diesel fuel at a concentration of $0.1 \mathrm{~mL} /$ plate was used as a carbon source.

Biodegradation of crude oil. The ability of strains Arthrobacter sp. M1 and Acinetobacter sp. Pr82 to degrade crude oil was investigated under sterile conditions in $250 \mathrm{~mL}$ flasks with $50 \mathrm{~mL}$ of mineral medium. Crude oil was used 
at a concentration of $2 \mathrm{mg} / \mathrm{mL}$. Experimental flasks with $10 \%(\mathrm{v} / \mathrm{v})$ of inoculum added and blank flasks were incubated in a rotary shaker at $30{ }^{\circ} \mathrm{C}$ and $200 \mathrm{rpm}$. The influence of inoculum age, inoculum volume, medium $\mathrm{pH}$, crude oil concentration and temperature on the intensity of crude oil degradation was investigated under the same cultivation conditions.

Crude oil degradation dependency on inoculum age was investigated with $0 ; 2 ; 4 ; 6$ and $8 \mathrm{~h}$ old inoculum.

Crude oil degradation dependency on inoculum volume was investigated with $2.5 ; 5 ; 7.5$; 10 and $15 \%$ (v/v) of inoculum.

Crude oil degradation dependency on medium $\mathrm{pH}$ was investigated at $\mathrm{pH}$ values of: 5 ; 6; 7; 8 and 9.

Crude oil degradation dependency on temperature was estimated at $5 ; 10 ; 20 ; 30 ; 40{ }^{\circ} \mathrm{C}$; and dependency on concentration was investigated with $1 ; 2 ; 3 ; 4$ and $5 \mathrm{mg} / \mathrm{mL}$ of crude oil.

After $24 \mathrm{~h}$ incubation, the cultures were extracted with an equal volume of trichlormethane for IR spectroscopy.

Infrared spectroscopy analysis. Samples were quantified with oil hydrocarbons Analyzer "HC 404" at a fixed wavelength $\left(2924 \mathrm{~cm}^{-1}\right)$.

SARA fractions determination. SARA fractions of crude oil were determined using gravimetric and liquid chromatography methods. Hydrocarbons were extracted with trichlormethane. After the evaporation of the solvent, hydrocarbons were again dissolved in n-pen- tane. Since asphaltenes are insoluble in n-pentane, they were separated by centrifugation. Their amount was calculated using a gravimetric method. Crude oil compounds soluble in $\mathrm{n}$-pentane were fractioned into saturated, aromatic and resin fractions by liquid chromatography methods, using different solvent phases: n-hexane (for saturated compounds), a mixture of $\mathrm{n}$-hexane and trichlormethane $(1: 1 \mathrm{v} / \mathrm{v}$; for aromatic) and a mixture of trichlormethane and methanol (1:1 v/v, for resins). All samples were analysed in triplicate and the results were expressed as mean value and standard deviation.

\section{RESULTS AND DISCUSSION}

Usually microorganisms are used for biological degradation when they are in exponential growth phase and when their reproductive processes are at peak. Therefore, in order to effectively apply the biological preparation for cleaning the environment from oil hydrocarbons, it is important to investigate the dependence of the activity of bacteria strains Arthrobacter sp. M1 and Acinetobacter sp. Pr82 on the culture growth phase (Grigiškis et al., 2005).

Substrate degradation level depends on the inoculum growth time. The greatest crude oil degradation (48\%) with Acinetobacter sp. Pr82 occurred when the substrate was inoculated with 8-hour old inoculum, which was in its stationary phase (Fig. 1). With Arthrobacter sp.

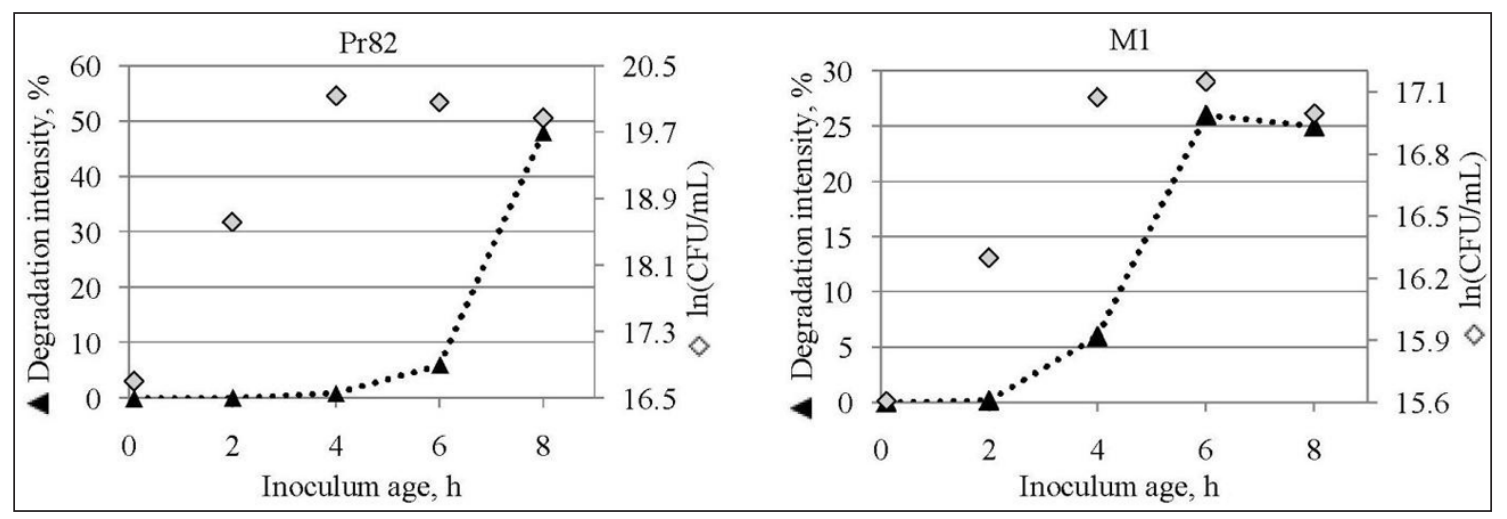

Fig. 1. The influence of Acinetobacter sp. Pr82 and Arthrobacter sp. M1 inoculums age on crude oil degradation intensity 
M1 we achieved similar results. The best degradation intensity (26\%) was obtained with 6-8hour old inoculum, which was in a stationary phase (Fig. 1). 8-hour old inoculum was used in all later experiments.

The effect of inoculum volume on crude oil degradation with Acinetobacter sp. Pr82 and Arthrobacter sp. M1 strains was investigated following the investigation into the effect of inoculum age. As seen in Fig. 2, the inoculum volume has little effect on crude oil degradation. Degradation intensity varies as little as 1 percent using $10 \%$ and $15 \%(\mathrm{v} / \mathrm{v})$ of inoculum. $10 \%(\mathrm{v} / \mathrm{v})$ of inoculum was used for the later experiments.

Extreme values of $\mathrm{pH}$ can inhibit microbial growth by interfering with the following: microbial metabolism, gas solubility, nutrient availability in soil and water, heavy metal solubility. Most natural environments have $\mathrm{pH}$ values between 5.0 and 9.0. Consequently, this range is optimal for microbe-enhanced biodegradation of waste contamination. During the selection of an optimal medium $\mathrm{pH}$, the maximum substrate degradation with Arthrobacter sp. M1 and Acinetobacter sp. Pr82 bacteria strains was achieved at $\mathrm{pH}$ range 7 , while more alkaline or acidic medium has prevented effective oil degradation (Fig. 3).

Most microbes prefer to grow at temperatures in a range of about 10 to $38^{\circ} \mathrm{C}$. The rate of biochemical reactions in cells increases with the temperature up to a maximum, above which the rate of activity declines as enzyme denaturation occurs and organisms either die or become less active. Low temperatures seldom kill the microbes, and with warming they typically recover.

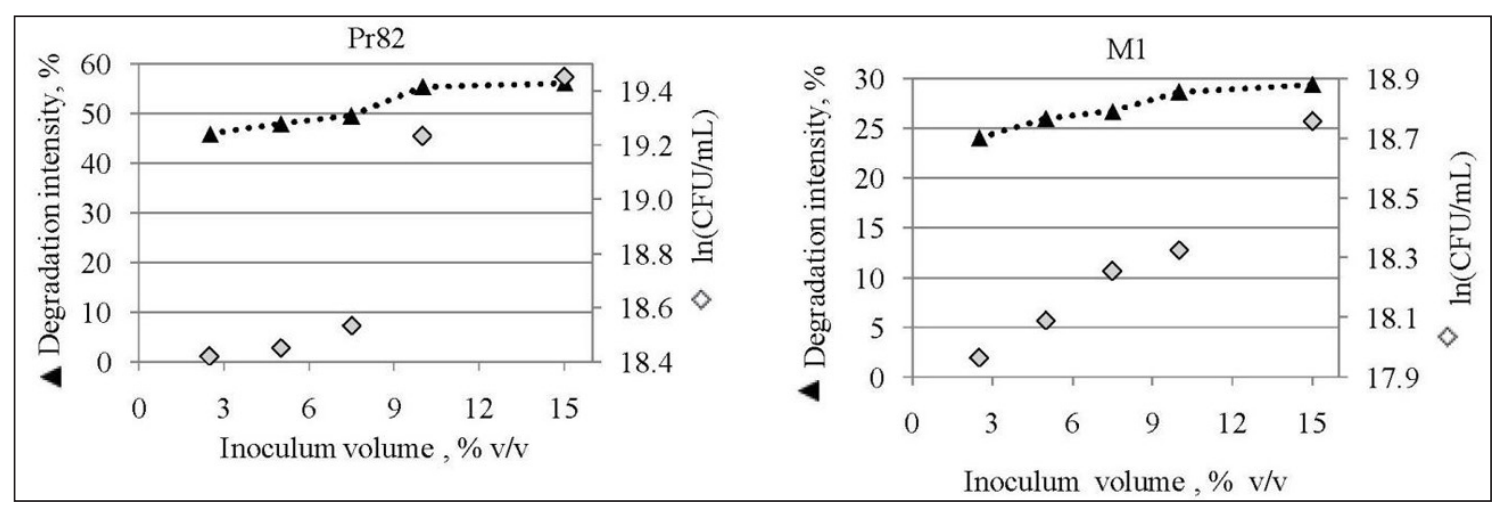

Fig. 2. Dependency of crude oil degradation by Acinetobacter sp. Pr82 and Arthrobacter sp. M1 strains on inoculum volume

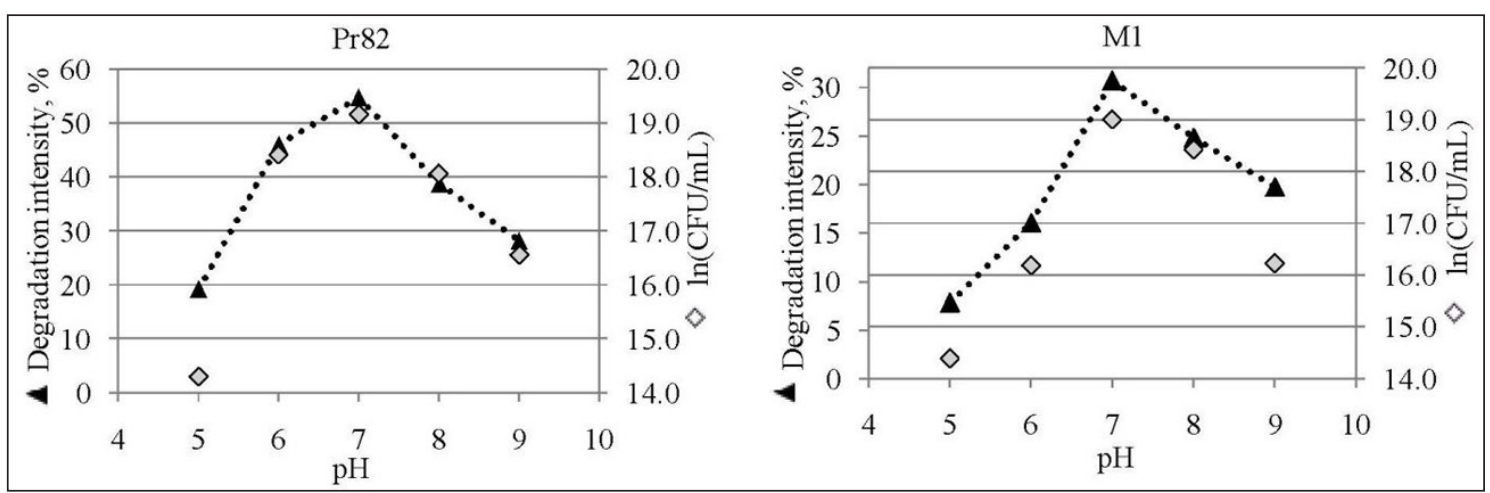

Fig. 3. Dependency of crude oil degradation by Acinetobacter sp. Pr82 and Arthrobacter sp. M1 strains on medium $\mathrm{pH}$ 
In this study, temperature regime for the most efficient pollutant degradation was selected. It was found that the increase in temperature from 5 to $30^{\circ} \mathrm{C}$ promotes degradation of substrate and it is highest at $30^{\circ} \mathrm{C}$, however, degradation level drops in the temperature range of $30-40{ }^{\circ} \mathrm{C}$ (Fig. 4).

The concentration of carbon source should be high enough to satisfy the needs for maintenance, energy and for processes that lead to the increase in cell size, growth, multiplication. If the initial concentration is too low, no growth of the original population will occur, resulting in a nondetectable decrease. The concentration at which no degradation will occur is the threshold concentration (in literature threshold value is approximately $1 \mu \mathrm{g} / \mathrm{kg}$ ).

The oxidizing properties of Acinetobacter sp. Pr82 and Arthrobacter sp. M1 strains were tested against the crude oil substrate. The best substrate degradation was observed when the initial crude oil concentration in the medium was $1 \mathrm{mg} / \mathrm{mL}$; higher concentrations slowed down the intensity of degradation (Fig. 5).

Aliphatic and some aromatic fractions of hydrocarbons are mostly biodegradable components, whereas resins and asphaltenes are considered as the most resistant to biodegradation (Ogbo and Okhuoya, 2008). Degradation level of different oil hydrocarbon groups depends not only on the composition of oil, but also on the capability of microorganisms to degrade different classes of oil hydrocarbons. Firstly, microorganisms degrade the most available hydrocarbons and their concentration decreases; the degradation process also slows down, as the remaining hydrocarbons

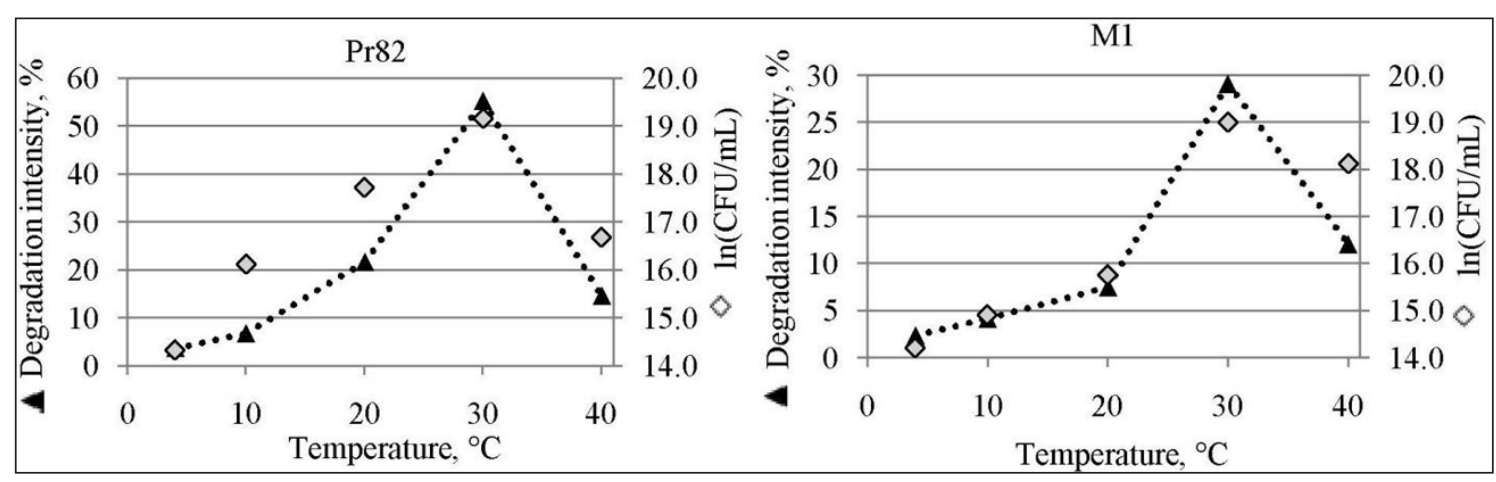

Fig. 4. Dependency of crude oil degradation by Acinetobacter sp. Pr82 and Arthrobacter sp. M1 strains on temperature

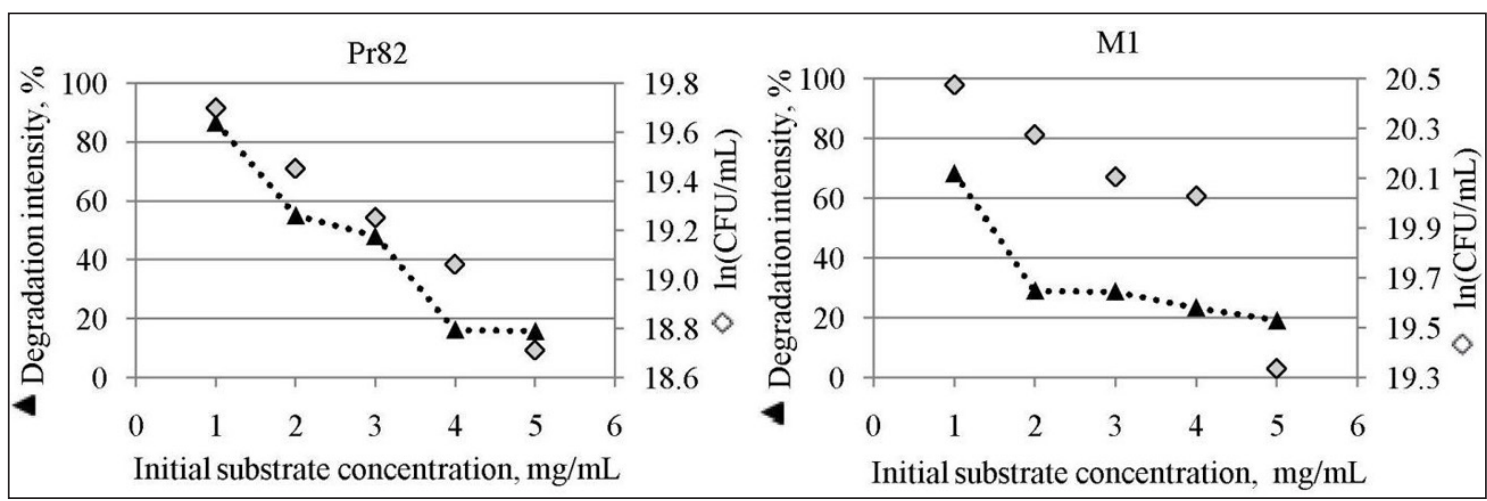

Fig. 5. Dependency of crude oil degradation by Acinetobacter sp. Pr82 and Arthrobacter sp. M1 strains on crude oil concentration 
are more difficult to degrade. Therefore, the composition of hydrocarbons changes when degradation of some oil hydrocarbons exceeds the degradation of others. However, when a mixed substrate of hydrocarbons is investigated, the compounds resistance to biodegradation is harder to observe. Environmental conditions and chemical composition of petroleum products influence the intensity of biodegradation.

Comparing the results of hydrocarbon group degradation levels in liquid medium with the initial crude oil concentration of $2 \mathrm{mg} / \mathrm{mL}$ by Acinetobacter sp. Pr82 and Arthrobacter sp. M1 strains, we can conclude that the hydrocarbon group composition has changed after 72 hours of the experiment (Fig. 6).
Greater changes in the oil component level were found after 72 hours of degradation by Acinetobacter sp. Pr82 strain. The investigation results show that microorganisms are the most effective in degrading saturated hydrocarbons, while asphaltenes and resins are degraded more slowly. It is clear that after degradation by Acinetobacter sp. Pr82 (Fig. 6b), the level of saturated compounds is lower (59.6\%) than in the initial crude oil composition (65.9\%, Fig. 6a); after degradation by Arthrobacter sp. M1 strain, the level of these compounds is $61.3 \%$ (Fig. 6c). In both cases aromatic compounds, resins and asphaltenes were higher in percentage after biodegradation when compared to the initial oil component groups. It shows that these compounds are degraded more slowly than saturated compounds.

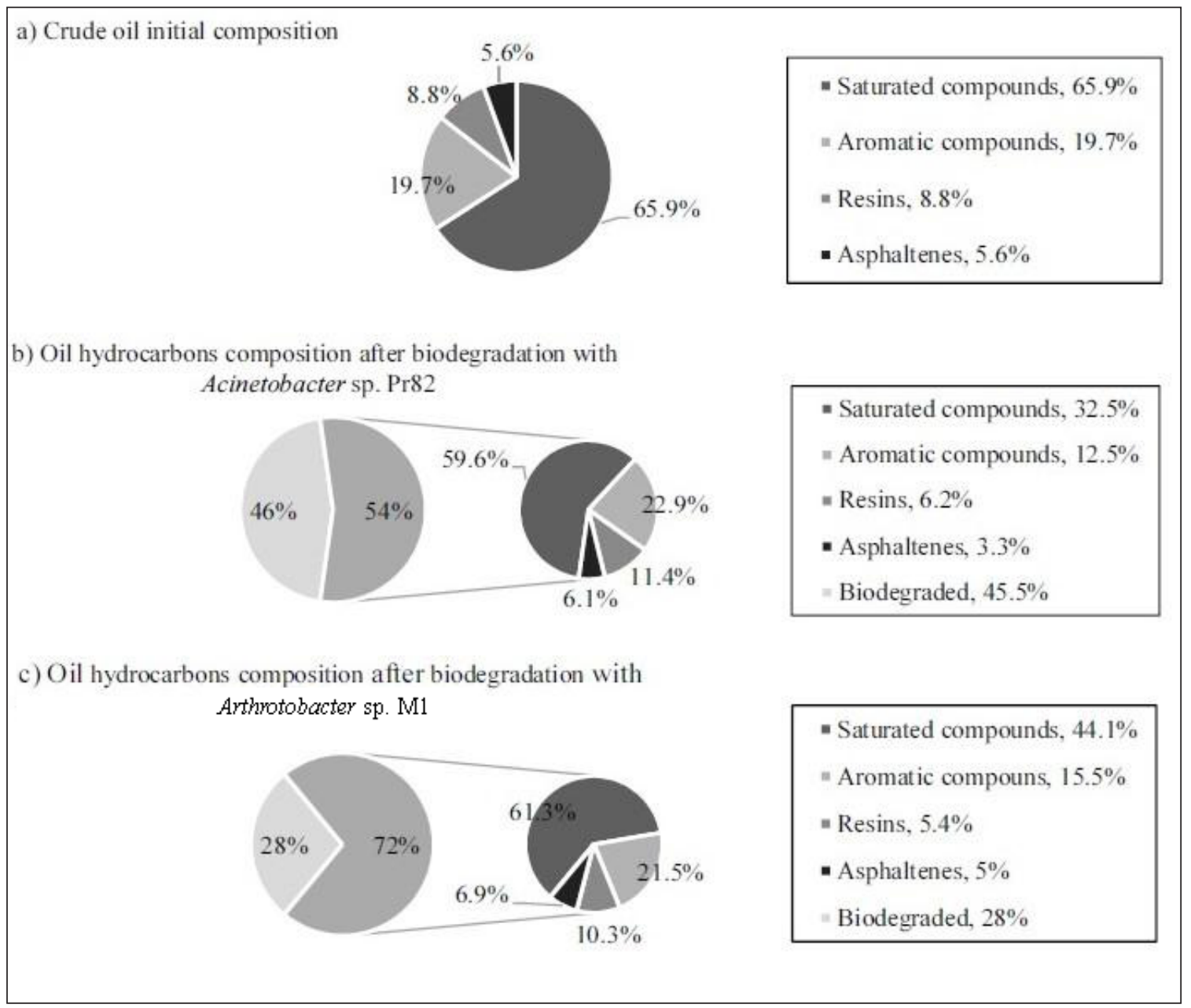

Fig. 6. Composition of crude oil components after a 72 hour biodegradation by Acinetobacter sp. Pr82 and Arthrobacter sp. M1 


\section{CONCLUSIONS}

1. The highest substrate degradation level by Acinetobacter sp. Pr82 and Arthrobacter sp. M1 strains were reached using 8-hour old inoculate culture which was in the stationary growth phase.

2. Inoculum volume has little effect on the degradation intensity of the crude oil.

3. The highest intensity of crude oil degradation by Acinetobacter sp. Pr82 and Arthrobacter sp. M1 strains occurred when the initial medium $\mathrm{pH}$ value was 7.0.

4. The temperature of $30^{\circ} \mathrm{C}$ was found to be the most optimal for crude oil degradation by both bacterial strains used for the experiments.

5. The highest substrate degradation level with Acinetobacter sp. Pr82 and Arthrobacter sp. M1 strains was reached when the initial crude oil concentration was $1 \mathrm{mg} / \mathrm{mL}$, medium $\mathrm{pH} 7.0$ and temperature $30^{\circ} \mathrm{C}$.

6. Both strains used for the experiments show the best results in biodegradation of saturated hydrocarbons and much lower degradation of aromatic compounds, resins and asphaltenes.

7. During all biodegradation experiments the results obtained with Acinetobacter sp. Pr82 were significantly greater than with Arthrobacter sp. M1.

Received 29 May 2014

Accepted 08 September 2014

\section{References}

1. Akpor OB, Igbinosa OE, Igbinosa OO. Studies on the effect of petroleum hydrocarbon on the microbial and physico-chemicals characteristics of soil. Afr J Biotechn 2007; 6: 1939-43.

2. Amro MM. Treatment techniques of oil-contaminated soil and water aquifers. International conference on water resources and arid environment; 2004.

3. Atlas RM. Microbial degradation of petroleum hydrocarbons: an environmental perspective.
Microbiol Rev 1981; 45(1): 180-209.

4. Fritshe W, Hofrichter M. Aerobic degradation by microorganisms. Biotechn Env Process II 2008; 11b: 145-55.

5. Gailiūtė I, Kavaliauskẻ M, Aikaitè-Stanaitienè J. Changes in total oil hydrocarbons composition during degradation with sorbent bacterial preparation. Biologija 2011; 57(2): 70-7.

6. Grigiškis $\mathrm{S}$, Čipinytė V, Levišauskas $\mathrm{D}, \mathrm{Baš-}$ kys EV. Optimization of Arthrobacter strain cultivation for degradation of the oil hydrocarbons. Latvij Kimij Zurn 2005; 1: 68-76.

7. Harayama S, Kasai Y, Hara H. Microbial communities in oil-contaminated seawater. Curr Opin Biotechn 2004; 15: 205-14.

8. Leahy JG, Colwell RR. Microbial degradation of hydrocarbons in the environment. Microbiol Rev 1990; 54(3): 305-15.

9. Levišauskas D, Tekorius T, Čipinytè V, Grigiškis S. Experimental optimization of nutrient media for cultivation of Arthrobacter sp. bacteria. Latvij Kimij Zurn 2004; 1: 75-80.

10. Montiel C, Quintero R, Aburto J. Petroleum biotechnology: Technology trends for the muture. Afr J Biotechnol 2009;12: 2661.

11. Ogbo EM, Okhuoya JA. Biodegradation of aliphatic, aromatic, resinic and asphaltic fractions of crude oil contaminated soils by Pleurotus tuber-regium Fr. Singer-a white rot fungus. Afr J Biotechnol 2008; 7(23): 4291-7.

12. Saadoun I, Munir JM, Hameed KM, Shawaqfah M. Microbial populations of crude oil spill polluted soils at the Jordan-Iraq desert (the Badia region). Brazil J Microbiol 2008; 39: 453-6.

13. Singh H. Mycoremediation: fungal bioremediation. John Wiley \& Sons inc., Hoboken, 2 New Jersey 2006; 454-532 (592).

14. Toledo FL, Calvo C, Rodelas B, GonzalezLopez J. System Appl Microbiol 2006; 29: 24452.

15. Towner K. The genus Acinetobacter. Prokaryotes. 2006 ; 6: 746-58. 
16. Van Hamme JD, Singh A, Ward OP. Recent advances in petroleum microbiology. Microbiol Molec Biol Rev 2003; 67(4): 503-49.

17. Zhang Z, Hou Z, Yang C, Maa C, Tao F, Xu P. Degradation of $n$-alkanes and polycyclic aromatic hydrocarbons in petroleum by a newly isolated Pseudomonas aeruginosa DQ8. Biores Technol 2011; 102: 4111-6.

Indrè Gailiūtè, Gražina Račkauskienė, Saulius Grigiškis

NAFTĄ SUDARANČIŲ JUNGINIŲ FRAKCINĖS SUDĖTIES POKYČIAI SKAIDANT NAFTĄ ATRINKTOMIS GERIAUSIOMIS

SĄLYGOMIS ARTHROBACTER SP. M1 IR ACINETOBACTER SP. PR82 BAKTERIJŲ KAMIENAIS

\section{Santrauka}

Viena iš perspektyviausių biotechnologijos taikymo sričių yra naftos angliavandeniliais užterštos aplinkos valymas. Ši biotechnologijos kryptis re- miasi mikroorganizmų gebėjimu skaidyti žaliavinę naftą ir naftos produktus. Plačiai paplitusios ir sugebančios išgyventi ekstremaliomis sąlygomis ypač patrauklios yra Arthrobacter ir Acinetobacter genties bakterijos (Levišauskas et al., 2004; Towner, 2006). Šio darbo tikslas - atrinkti geriausias sąlygas (pasejjamosios kultūros amžių ir tūrị, temperatūrą, $\mathrm{pH}$, koncentraciją) skaidyti žaliavinę naftą ir ištirti, kaip keičiasi SADA frakcijų (sočiujų ir aromatinių junginių, dervų ir asfaltenų) santykis atrinktomis geriausiomis sąlygomis skaidant naftą mikroorganizmais. Tyrimams naudoti Arthrobacter sp. M1 ir Acinetobacter sp. Pr82 bakterijų kamienai iš UAB „Biocentras“ mikroorganizmų kolekcijos. Atlikus bandymus nustatyta, kad Arthrobacter sp. M1 ir Acinetobacter sp. Pr82 geriausiai skaidè sočiųjų junginių frakciją, daug lèčiau buvo skaidomi aromatiniai junginiai, dervos ir asfaltenai.

Raktažodžiai: žaliavinè nafta, Arthrobacter sp., Acinetobacter sp., biologinis skaidymas, SADA (sotieji junginiai, aromatiniai junginiai, dervos, asfaltenai) frakcijos 